\title{
Pengaruh Insentif Terhadap Motivasi Kerja di Auto 2000 Raden Intan Bandar Lampung
}

\author{
M Yusuf S Barusman, Elizabeth Amelia \\ Fakultas Ekonomi dan Bisnis, Universitas Bandar Lampung, Indonesia \\ Email : \\ yusuf.barusman@ubl.ac.id \\ Elizabethamelia1995@yahoo.co.id
}

\begin{abstract}
ABSTRAK
Peranan tenaga kerja bagi perusahaan sangatlah penting, sehingga perusahaan berusaha untuk mempertahankan dan menjaga agar karyawan betah bekerja di perusahaannya, dan usaha yang dilakukan perusahaan adalah dengan memberikan balas jasa yang memadai untuk karyawannya. Insentif adalah salah satu bentuk balas jasa dan juga merupakan sarana untuk memotivasi karyawan agar dapat bekerja lebih giat lagi. Auto 2000 Raden Intan Bandar Lampung merupakan salah satu perusahaan yang bergerak di bidang otomotif. Motivasi kerja karyawan Auto 2000 Raden Intan Bandar Lampung dinilai menurun disebabkan karena kurangnya motivasi dan tidak sesuainya pemberian insentif. Hal ini dapat dilihat dari data absensi karyawan Auto 2000 Raden Intan pada tahun 2015 yang masih tergolong tinggi dari batas yang ditolerir oleh perusahaan, dan berdasarkan data kepuasan tentang insentif di Auto 2000 Raden Intan masih banyak karyawan yang merasa tidak puas terhadap insentif yang diterima. Hal ini diperkuat oleh teori Herzberg yaitu terdapat 2 faktor yang mempengaruhi motivasi yaitu faktor Hygiene dan motivator.

Penelitian ini bertujuan untuk mengetahui pengaruh variable insentif terhadap motivasi kerja di Auto 2000 Raden Intan Bandar Lampung. Populasi dalam penelitian ini sebanyak 45 orang karyawan. Sampel diambil dari keseluruhan jumlah karyawan Auto 2000 Raden Intan karena jumlah karyawannya dibawah 100. Analisa dalam penelitian ini menggunakan persamaan regresi linear sederhana dengan hasil menunjukan bahwa terjadinya motivasi yang baik dipengaruhi oleh insentif. Hasil uji Koefisien Korelasi menunjukan hubungan linear positif (searah) antara insentif dengan motivasi kerja. Dan hasil nilai $\mathrm{R}^{2}$ (Koefisien Determinasi) menunjukan bahwa motivasi kerja di Auto 2000 Raden Intan Bandar Lampung dipengaruhi oleh factor Insentif sebesar 29,8\% sedangkan sisanya sebesar 70,2\% motivasi kerja dipengaruhi oleh variabel lain yang tidak diteliti dalam penelitian ini.
\end{abstract}

\section{Kata Kunci: Insentif; MotivasiKerja; Regresi}

\section{PENDAHULUAN}

Perkembangan dunia usaha tidak dapat di pisahkan dari perkembangan sumberdaya terutama sumber daya manusia yang ada di dalamnya. Perusahaan dalam meningkatkan kinerjanya, haruslah mempunyai komitmen terhadap pengembangan kualitas sumber daya manusia yang dimiliki. Motivasi merupakan hal yang sangat penting yang harus dimiliki oleh setiap individu dalam bekerja.

Penurunan motivasi dapat terjadi dikarenakan perusahaan kurang memperhatikan pemberian insentif, karena insentif adalah salah satu bentuk balas jasa dan juga merupakan sarana untuk memotivasi karyawan agar dapat bekerja lebih giat lagi. Berdasarkan hasil penelitian awal di Auto 2000 Raden Intan tentang tingginya tingkat absensi karyawan Auto 2000 Raden Intan Bandar Lampung yaitu sebesar 3,4\%. Angka ini masih lebih tinggi dari batas yang ditolerir perusahaan yaitu sebesar 2,5\%. Kemudian berdasarkan data tentang kepuasan terhadap insentif di Auto 2000 Raden Intan Bandar Lampung, masih banyak karyawan yang tidak puas terhadap insentif dengan persentasi sebesar $63 \%$, dibandingkan dengan yang puas terhadap insentif di Auto 2000 Raden Intan Bandar Lampung dengan presentase sebesar 37\%.

Dalam penelitian ini tujuan yang ingin dicapai adalah untuk mengetahui apakah insentif material dan non material mempunyai pengaruh yang signifikan terhadap motivasi kerja di Auto 2000 Raden Intan Bandar Lampung. 


\section{METODOLOGI PENELITIAN}

Teori Motivasi yang digunakan dalam penelitian ini adalah Teori motivasi Frederich Herzberg (Teori Dua Faktor), yaitu seseorang terdorong untuk melakukan pekerjaan karena disebabkan oleh dua faktor yaitu faktor motivator dan hygiene. Faktor motivator adalah faktor-faktor motivasi yang menyangkut kebutuhan psikologis yang berhubungan dengan penghargaan terhadap prestasi secara langsung berkaitan dengan pekerjaan, terdiri dari: keinginan untuk berprestasi tinggi, pengakuan, pekerjaan itu sendiri, tanggung jawab, kemajuan dan peningkatan. Sedangkan faktor Hygiene adalah faktor-faktor motivasi yang menyangkut dengan hubungan kerja dengan lingkungan kerja dimana karyawan bekerja. Suatu pekerjaan yang menyebabkan rasa tidak puas diantara para bawahan, terdiri dari: gaji atau upah, pengawasan, kondisi kerja yang memadai, hubungan antar pribadi, kebijakan dan administrasi perusahaan (Siswanto 2003:146) ${ }^{1}$.

Teori tentang insentif yang digunakan dalam penelitian ini adalah teori insentif Garry Dessler yang mengemukakan Insentif populer dengan sebutan Insentif finansial (financial incentives). Insentif finansial merupakan hadiah atau bonus finansial yang diberikan kepada karyawan atas kelebihan produktivitas mereka diatas standar yang telah ditentukan oleh organisasi. Menurut Gary Dessler (2007:104) ${ }^{2}$ menjelaskan bahwa insentif dibedakan atas dua jenis yaitu insentif material dan insentif non material. Insentif Financial / Material adalah beberapa sistem penghargaan berupa financial yang diberikan dalam bentuk uang sebagai alat utama yang dapat membantu manusia dalam memenuhi kebutuhan pokok mereka. Dalam pemberian insentif ini terdapat perbedaan, hal ini disebabkan adanya tingkat atau golongan yang berbeda dari setiap karyawan dalam suatu perusahaan, contohnya berupa: Bonus, Profit Sharing. Dan Insentif non financial / non material adalah suatu insentif bagi para karyawan yang bukan merupakan kebutuhan berwujud uang contohnya berupa: Terjaminnya kenyamanan tempat kerja, Terjaminnya komunikasi yang baik antara atasan dan bawahan, Adanya penghargaan berupa pujian atau pengakuan atas kerja yang baik, pemberian promosi (kenaikan pangkat atau jabatan).

Penelitian ini merupakan penelitian kuantitatif, sebagaimana pendapat Sugiyono
(2008:23) $)^{3}$ bahwa penelitian kuantitatif adalah penelitian yang menggunakan data penelitian yang berupa angka-angka dan analisis menggunakan statistik.

Desain penelitian ini adalah deskriptif yaitu desain penelitian yang dilakukan untuk mengetahui nilai variabel, baik satu variabel atau lebih yang menghubungkan dengan variabel yang lain (Sugiyono, 2008:5) .

Menurut Sugiyono $(2005)^{5}$ populasi adalah wilayah generalisasi yang terdiri atas objek/subjek yang mempunyai kualitas dan karakteristik tertentu yang ditempatkan oleh peneliti untuk dipelajari kemudian ditarik kesimpulannya. Populasi dalam penelitian ini adalah karyawan Auto 2000 RadenIntan di Bandar Lampung. Jumlah populasi dalam penelitian ini adalah 45 orang karyawan. Menurut Arikunto (2008) ${ }^{6}$ penentuan pengambilan sampel adalah apabila kurang dari 100 lebih baik diambil semua sehingga penelitiannya merupakan penelitian dengan metode sensus.

Penelitian ini juga menggunakan uji Validitas dan uji Reliabilitas. Uji Validitas digunakan untuk mengukur sah atau tidak sahnya suatu kuesioner. Kuesioner dikatakan valid apabila pertanyaan pada kuesioner mampu mengungkap sesuatu yang akan diukur oleh kuesioner itu. Validitas yang digunakan dalam penelitian ini (contentvalidity) menggambarkan kesesuaian sebuah pengukur data dengan apa yang akan diukur (Sugiyono, 2012) ${ }^{7}$. Uji Reliabilitas adalah alat uji untuk mengukur kuesioner yang merupakan indikator dari variabel. Apabila suatu alat ukur memberikan hasil yang stabil, maka disebut alat ukur itu handal. Hasil ukur itu diterjemahkan dengan koefisien keandalan yaitu derajat kemampuan alat ukur mengukur perbedaan-perbedaan individu yang ada. Keandalan itu perlu, sebab data yang tidak andal atau bisa tidak dapat diolah lebih lanjut.

Metode analisis data dalam penelitian ini menggunakan analisis data kualitatif dan kuantitatif. Analisis data kualitatif, yaitu analisis yang dinyatakan dalam bentuk uraian dan didasarkan pada data yang telah ada dan dari penelitian lapangan. Kemudian data tersebut akan dikemukakan dalam bentuk tabel beserta penyelesaiannya dan selanjutnya akan digolongkan sesuai dengan ketentuannya. Data kualitatif selanjutnya akan dikaitkan dengan data lainnya sehingga memunculkan suatu kebenaran. Analisis ini berguna untuk menjelaskan tentang 
berbagai macam masalah atau hal-hal penting yang dinyatakan dalam bentuk kalimat.

Analisis Data Kuantitatif adalah metode yang dilakukan dengan perhitungan menggunakan alat analisis yang bersifat kuantitatif seperti rumusrumus, alat dan model-model analisis (hasil perhitungan) yang kemudian dijelaskan makna dari angka-angka tersebut serta disimpulkan. Metode pengolahannya berupa editing (pengeditan), cording (pemberian kode), scorcing (pemberian skor).

Analisis Regresi Linier Sederhana dapat digunakan untuk memprediksikan seberapa jauh hubungan fungsional ataupun kausal satu variabel independen dengan satu variabel dependen (Sugiyono, 2012) ${ }^{8}$.

Koefisien Korelasi adalah analisis korelasional digunakan untuk melihat kuat lemahnya antara variabel bebas dengan tergantung (Sarwono,2006) ${ }^{9}$. Selain pengertian di atas analisis korelasi juga digunakan untuk mengetahui derajat korelasi antara kedua variabel, sehingga digunakan analisis korelasi product moment yang bertujuan untuk mengetahui ada atau tidaknya hubungan dua variabel yaitu variabel bebas dan variabel terikat.

Koefisien Determinasi $\left(\mathrm{R}^{2}\right)$ pada intinya digunakan untuk mengukur seberapa jauh kemampuan dalam menerangkan variasi variabel dependen. Nilai koefisien determinasi adalah antara nol (0) dan satu (1) (Ghozali, 2009) ${ }^{10}$.

\section{HASIL DAN PEMBAHASAN}

\section{Uji Validitas}

Berdasarkan hasil uji validitas instrument penelitian didapai bahwa seluruh butir pernyataan yang ada pada kuisioner (X1-X10 dan Y1-Y10), mempunyai koefisien korelasi yang lebih besar dari r-tabel (nilai r-tabel untuk $\mathrm{N}=45$ dengan tingkat signifikansi 0,5\%). Dengan demikian seluruh butir pernyataan yang dilampirkan dalam kuisioner dinyatakan valid.

\section{Uji Reliabilitas}

Kemudian dari hasil uji reliabilitas diketahui bahwa seluruh variabel memiliki Cronbach's Alpha lebih besar dari 0,6 sehingga semua variabel dan dimensi penelitian dinyatakan reliabel, dan dasar indikator ini yang akan digunakan pada analisa lebih lanjut.

\section{Regreasi Linear Sederhana}

Dari hasil perhitungan, berdasarkan rumus $\mathrm{Y}=\mathrm{a}$ + bX maka didapat persamaan regresi linier sederhana $\mathrm{Y}=17,840+0,512 \mathrm{X}$, artinya bahwa jika tidak ada peningkatan Insentif maka Motivasi Kerja konstanta menjadi 17,840. Jika terdapat peningkatan Insentif maka akan meningkatkan Motivasi Kerja.

Nilai koefisien untuk variabel Insentif (X) sebesar 0,512 mengandung arti bahwasannya terdapat pengaruh positif antara variabel Insentif (X) terhadap variabel Motivasi Kerja (Y) pada Auto 2000 Raden Intan Bandar Lampung, sehingga pada setiap peningkatan atau kenaikan poin yang dilakukan terhadap variabel Insentif (X) sebesar 1 unit, maka akan meningkatkan variabel Motivasi Kerja (Y) pada Auto 2000 Raden Intan Bandar Lampung sebesar 0,512 poin pada konstanta 17,840 .

Maka dapat di simpulkan dari kedua variabel tersebut menunjukkan bahwa terjadinya Motivasi Kerja di Auto 2000 Raden Intan Bandar Lampung yang baik dipengaruhi oleh Insentif yang diberikan oleh perusahaan.

\section{Koefisien Korelasi}

Berdasarkan hasil perhitungan, diperoleh nilai koefisien korelasi (r) sebesar 0,561 artinya bahwa hubungan kedua variabel berpengaruh positif. Nilai $\mathrm{r}=0,561$ menunjukkan hubungan linier positif (searah) antara Insentif dengan Motivasi Kerja artinya semakin besar Insentif yang diberikan oleh Auto 2000 Raden Intan kepada karyawannya maka semakin positif hubungan diantara kedua variabel.

\section{Koefisien Determinasi}

Hasil perhitungan regresi dapat diketahui bahwa koefisien determinasi (adjusted $\mathrm{R}^{2}$ ) yang diperoleh sebesar 0,298 hal ini berarti Motivasi Kerja di Auto 2000 Raden Intan Bandar Lampung dipengaruhi oleh faktor Insentif sebesar 29,8\% sedang kan sisanya yaitu 70,2\% Motivasi Kerja dipengaruhi oleh variabelvariabel lainnya yang tidak diteliti dalam penelitian ini.

Fakta dilapangan menunjukan masih banyak karyawan yang mengeluh mengenai insentif mereka. Hal ini disebabkan masalah ketidakcukupan insentif yang diberikan kepada karyawan, dimana ada beberapa karyawan yang merasa bahwa insentif yang mereka terima belum sesuai dengan tingkat jabatan mereka, insentif yang diberikan oleh perusahaan terkadang kurang menarik dan membuat karyawan tidak semangat 
bekerja, insentif yang diberikan belum mendukung para karyawan untuk bekerja lebih giat karena ketidaksesuaiannya pemberian insentif, belum sesuainya tunjangan yang diberikan oleh perusahaan terhadap karyawan, karyawan merasa masih ada ketelatan dalam pemberian asuransi sehingga karyawan merasa tidak aman dalam bekerja, dalam pemberian penghargaan kurang baik karena tidak selalu dipantau oleh atasan, ada beberapa pekerjaan yang menarik dan juga ada yang tidak menarik yang menyebabkan karyawan bermalas-malasan, karyawan merasa kurang cukup nyaman dengan hubungan antar karyawan karena kurang adanya rasa kerja sama yang baik, kemudian target yang ditentukan sudah cukup baik hanya terkadang banyak karyawan yang tidak memaksimalkan waktu tersebut, dan mengenai prosedur perusahaan yang harus dipatuhi karyawan, sebagian karyawan sudah mengikuti prosedur perusahaan yang ada tetapi prosedur tersebut bisa kapan saja berubah.

Untuk tingkat motivasi karyawan Auto 2000 Raden Intan Bandar Lampung, karyawan belum sepenuhnya termotivasi. Bisa dilihat dari fakta dilapangan yang didapat bahwa, menurut jawaban responden gaji yang mereka peroleh sudah cukup untuk kehidupan sehari-hari walaupun terkadang adanya kekurangan, tunjangan sudah mengikuti peraturan pemerintah hanya saja perusahaan belum memaksimalkan peraturan tersebut, kebijakan atasan dalam pemberian insentif cukup baik sesuai dengan kinerja karyawan tetapi belum maksimal karena sering terjadi keterlambatan pemberian insentif, karyawan merasa pekerjaan mereka bisa menjadi bekal untuk masa depan dan bisa mereka tekuni, apabila karyawan selalu giat bekerja maka bisa memperoleh penghargaan yang diberikan oleh atasan, karyawan merasa cukup nyaman dengan hubungan antara atasan dan rekan kerja, karyawan merasa pengawasan pimpinan terhadap bawahan sudah baik karena selalu dipantau dan diberikan arahan setiap kali ada kesalahan, karyawan merasa kondisi ruang kerja yang nyaman sehingga merasa betah bekerja di dalam kantor, kemudian karyawan merasa kurang baiknya lingkungan didalam kantor yang terkadang tidak bersih, panas dan aroma yang tidak sedap, dan beberapa karyawan yang menilai kurang berkembangnya mereka dalam bekerja yang mengakibatkan mereka tidak giat bekerja.

Dapat disimpulkan bahwa motivasi karyawan dipengaruhi oleh insentif yang meliputi upah, gaji, tunjangan, dll. Insentif merupakan sarana penting untuk memotivasi karyawan dalam bekerja, dengan pemberian insentif yang sesuai maka membuat karyawan bekerja lebih giat lagi dan lebih termotivasi, dengan pemberian insentif yang tidak sesuai dan tidak tepat waktu akan membuat karyawan menjadi malas berkerja dan bekerja tidak sesuai target seperti yang ada di dalam Auto 2000 Raden intan, masih banyak karyawan yang tidak giat bekerja, malas bekerja dikarenakan insentif yang tidak sesuai dan tidak bisa memenuhi kebutuhan hidup mereka, karyawan pun merasa tidak termotivasi akan hal tersebut. Dilihat dari hasil penelitian terdahulu bahwa insentif material dan non material berpengaruh terhadap motivasi kerja. Hal ini diperkuat oleh teori Frederich Herzberg, yaitu sangat diperlukan faktor hygiene, karena di dalam faktor tersebut menyebutkan bahwa faktor hygiene meliputi gaji / insentif yang merupakan hal paling penting bagi karyawan, dengan pemberian gaji / insentif yang sesuai maka karyawan akan lebih termotivasi dan juga bisa berprestasi.

\section{KESIMPULAN DAN SARAN}

\section{Kesimpulan}

Berdasarkan kajian teoritik dan hasil analisis data pada sebelumnya, maka dapat disimpulkan bahwa :

Terdapat pengaruh positif dan signnifikan antara Insentif terhadap Motivasi Kerjadi Auto 2000 Raden Intan Bandar Lampung.

\section{Saran}

Berdasarkan kesimpulan yang diperoleh dalam penelitian ini, maka diajukan saran-saran sebagai pelengkap terhadap Motivasi Kerja yang dapat diberikan di Auto 2000 Raden Intan Bandar Lampung sebagai berikut:

1. Perusahaan harus meningkatkan pemberian insentif sesuai dengan berat ringannya beban tugas dan tanggung jawab pekerjaan setiap karyawan, dan juga perusahaan harus memberikan insentif berdasarkan hasil penilaian kinerja karyawan.

2. Perusahaan harus mempertahankan pekerjaan yang menarik dan membuat kinerja karyawan meningkat misalnya perusahaan memberikan pekerjaan yang sesuai dengan bidang karyawannya, contohnya karyawan yang terbiasa di 
lapangan belum tentu memiliki kinerja baik jika bekerja di belakang meja, maka karyawan diberikan tugas untuk turun langsung ke lapangan saat akan melakukan survey.

3. Perusahaan harus meningkatkan kesempatan pengembangan diri dan karir yang diberikan agar dapat mendorong karyawan bekerja dan berprestasi dengan baik dengan memberikan penjelasan mengenai alur peningkatan berkarir yang sistematis dan jelas.

\section{DAFTAR PUSTAKA}

Arikunto 2008. Penelitian Tindakan Kelas, Jakarta. PT. Bumi Aksara (6)

Dessler, Gary 2007, Manajemen Personalia, Edisi Ketiga, Jakarta: Erlangga.

Panggabean, Mutiara S. 2002. Manajemen

Sumber Daya Manusia. Bogor: Ghalia Indonesia. (2)

Ghozali, Imam. 2009. AplikasiAnalisis Multivariate Dengan Program SPSS, Edisi Keempat. Penerbit Universitas Diponegoro. (10)

Jonatan. Sarwono. 2006. Metode Penelitian Kuantitatif dan Kualitatif. Yogyakarta :GrahaIlmu. (9)

Siswanto Sastrohadiwiryo, 2003. Manajemen Tenaga Kerja Indonesia, Edisi 2, Jakarta, PT. Bumi Aksara. (1)

Sugiyono. (2012). Memahami penelitian kualitatif. Bandung: Alfabeta. (7\&8)

(2008). Metode Penelitian Kunatitatif Kualitatif dan R\&D. Bandung Alfabeta. (3\&4)

2005. Metode Penelitian

Administratif. Bandung Alfabeta. (5) 